УДК 373.3.015.31:172.15

DOI:

Наталія Калита, кандидат педагогічних наук, доцент кафедри педагогіки і методики початкової освіти Дрогобииького державного педагогічного університету імені Івана Франка

Микола Пантюк, доктор педагогічних наук, професор кафедри педагогіки і методики початкової освіти Дрогобииького державного педагогічного університету імені Івана Франка

\title{
НАЦІОНАЛЬНО-ПАТРІОТИЧНЕ ВИХОВАННЯ УЧНІВ ПОЧАТКОВОЇ ШКОЛИ
}

У статті розкрито питання начіонально-патріотичного виховання особистості; обтрунтовано поняття "національного” та “патріотичного” виховання; висвітлено особливості формування національнопатріотичних почуттів в учнів початкової школи; розкрито форми впровадження елементів національнопатріотичного виховання у школі. Встановлено, щуо основною метою начіонального виховання є передача молодому поколінню соціального досвіду, духовної культури народу, його ментальних настанов, світоглядних цінностей тощзо.

Ключові слова: начіонально-патріотичне виховання; початкова школа; особистість; учень.

Jim. 9.

Nataliya Kalyta, Ph.D. (Pedagogy), Associate Professor of the Pedagogy and Methods of Primary Education Department Drohobych Ivan Franko State Pedagogical University

Mykola Pantyuk, Doctor of Sciences (Pedagogy), Professor of the Pedagogy and Methods of Primary Education Department Drohobych Ivan Franko State Pedagogical University

\section{NATIONALAND PATRIOTIC EDUCATION OF PRIMARY SCHOOLCHILDREN}

The article reveals the issue of national and patriotic education of the personality; the concepts of "national" and "patriotic" education are substantiated; the features of the introduction and formation of national and patriotic education of students in the conditions of primary school are elucidated; forms of the introduction of national and patriotic education elements in school are revealed.

National and patriotic education is an important component of the educational process. Personality is an important pedagogical regularity in this process. It is during the development of personality that important effective ways of cognition take place; these are the ways of cognition from native to foreign, from near to far, from national to international, world one.

Such normative documents as the State national program "Education" ("Ukraine of the XXI century"), "National program of patriotic education of citizens, the development of spirituality", the Law of Ukraine "On Education", "National Doctrine of Education Development" outline a range of problems that reflect love to the Motherland, respect for symbols, awareness of the civil duty on the basis of national and universal values, affirmation of the personality as a citizen-patriot of his/her state.

The concept of national and patriotic education is revealed. National education is a system of views, beliefs, ideals created on the basis of the principles of national pedagogy and designed to form the worldview consciousness and value orientations of children and students. The article points out that the problem of national and patriotic education was studied by the leading figures of pedagogy K. Ushinsky,

V. Sukhomlynsky, G. Vashchenko, O. Vyshnevsky and others.

The conception of national and patriotic education of children and youth defines patriotic education as a component of national education. Its main goal is to become a self-sufficient citizen a patriot of Ukraine, ready to perform civil constitutional duties, to inherit the spiritual and cultural heritage of the Ukrainian people.

The main tasks of national and patriotic education are the development of high social activity, civil responsibility, spirituality in the society and also the formation of civil society. Civil society will consist of citizens who have a high level of consciousness and the ability to show it in everyday activities ensuring constant development.

Keywords: national and patriotic education; patriotism; national education; primary school; personality; student. 
непорушними і святими, обумовлюють важливість національно-патріотичного виховання молоді. Історичний досвід державотворення в Україні, консолідаційні зусилля народу протистояти російській агресії (з 2014 р.) та зберегти свою національну ідентичність актуалізують проблему формування в учнів почуття патріотизму в умовах школи та поза нею.

Державна національна програма "Освіта" (Україна XXI ст.), Закон України "Про освіту”, "Національна доктрина розвитку освіти" окреслюють коло завдань, вирішення яких сприяє розвитку в учнів почуття любові до Батьківщини, утверджує особистість як громадянина - патріота своєї держави, формує повагу до національних символів та усвідомлення своїх громадянських прав і обов'язків на основі поєднання національних і загальнолюдських цінностей.

Початкова школа $є$ першим ступенем обов'язкової загальної освіти, тим фундаментом, який відповідно до вікових особливостей та Державного стандарту формує життєво необхідні компетенції, закладає у свідомості дитини моральні цінності та якості особистості, пї світогляд. Головним завданням закладів освіти визначено, що “потрібно так будувати виховну діяльність, щоб приклади авторитетних учителів, шкільне середовище виховували дітей у дусі патріотизму” [5]. Для учнів важливо навчитися глибоко розуміти історію свого народу, особливості національної ідентичності, адже “завдання педагогів полягає в тому, щоб слова “Україна”, “патріотизм” не були пустими, а набували для дитини особливого сенсу, тобто сприймалися “не лише розумом, а й серцем” [5].

Національне виховання визначає зміст та систему принципів національної педагогіки, яка складається 3 народної творчості, надбань культури, літератури тощо. В енциклопедії освіти, зазначено що “національне виховання - це створена на основі принципів національної педагогіки система поглядів, переконань, ідеалів, покликаних формувати світоглядну свідомість та ціннісні орієнтації дітей і учнівської молоді...” [2].

Патріотичне виховання $\epsilon$ складовою національного виховання, в перекладі “патріотизм” означає “земля батька, предка”. У Енциклопедії освіти, В. Ткаченко зазначає, що “патріотизм в молодшого школяра проявляється через пізнання сторінок національної історії, великодушність і правосвідомість, жагу подвигу й служіння своєму народові, готовність терпіти і боротися" [11].

Аналіз останніх досліджень. Питання національно-патріотичного виховання не втрачало своєї актуальності упродовж усієї історії педагогіки, зокрема висвітлювалися у працях Г. Сковороди, К. Ушинського, В. Сухомлинського, Г. Ващенка та ін. Над проблемою реформування сучасного змісту освіти, виробленням та реалізацією засад особистісноорієнтованої освітньої парадигми, розробкою та впровадженням шляхів і засобів національного виховання дітей та учнівської молоді на сучасному етапі духовного розвитку національного відродження України працювали І. Бех, О. Вишневський, В. Кононенко, П. Кононенко, О. Кобрій, В. Кузь, М. Пантюк, Т. Пантюк, Ю. Руденко, М. Чепіль та ін. Розробки проблеми національно-патріотичного виховання молоді відображено у дисертаціях М. Качур, Л. Кулішенко, І. Лебідь та ін. Однак, незважаючи на чисельні напрацювання, проблема не втратила своєї актуальності, що обумовило вибір теми нашої статті.

Мета статті полягає в обгрунтуванні основ національно-патріотичного виховання та впровадженні його змісту в освітній процес сучасної початкової школи.

Виклад основного матеріалу. Вирішення проблеми національно-патріотичного виховання корелюється із завданням формування соціальних та громадянських компетентностей в учнів початкових класів, які орієнтовані на усвідомлення ідей справедливості, демократії, прав та обов'язків людини, добробуту та здорового способу життя, співпрацю з іншими людьми, уміння цінувати культурне розмаїття різних народів та ідентифікувати себе як громадянина України.

Національно-патріотичне виховання - це фундамент, методолого-філософська основа, найважливіший засіб і джерело формування особистісних рис громадянина України, незалежно від національної належності вихованця [2].

Головною метою національно-патріотичного виховання виступає прищеплення особистості віри в українську ідею, в основу якої покладено служіння Україні, через набуття молодим поколінням соціального досвіду; успадкування духовних надбань українського народу, настанов його національної ментальності, своєрідності світогляду. Виховання здатності зберігати свою національну ідентичність, досягнення високої культури міжнаціональних взаємин, розвиток духовних, фізично досконалих, різнобічно розвинених особистостей [2].

Спільною настановою низки концепцій та положень, освітньо-нормативних документів, законів, рекомендацій щодо національнопатріотичного виховання молодших школярів $\epsilon$ трактування цього освітнього напрямку у змісті, 
формах і засобах формування почуття любові та поваги до своїх батьків, Батьківщини, країни, території, поваги до народних звичаїв, традицій, рідної та державної мови, національної і державної символіки - Конституції, Герба, прапора, гімну України тощо. 3 цими напрямками учні ознайомлюються на уроках літературного читання, української мови, курсу “Я досліджую світ”, у позакласній та позашкільній діяльності початкової школи.

Головною особливістю національно-патріотичного виховання молодого покоління $є$ формування в особистості ціннісного ставлення до навколишнього середовища. В основу системи національно-патріотичного виховання покладено ідею розвитку української державності як консолідуючого чинника розвитку суспільства і нації в цілому. Форми і методи виховання базуються на українських народних традиціях, кращих надбаннях української національної та світової педагогіки [4].

Концепція національно-патріотичного виховання дітей та молоді визначає патріотичне виховання як складову національного виховання, головною метою якого є становлення самодостатнього громадянина - патріота України, готового до виконання громадянських конституційних обов'язків, до успадкування духовних і культурних надбань українського народу. Основними завданнями національно-патріотичного виховання визначено “розвиток у суспільстві високої соціальної активності, громадянської відповідальності, духовності, становлення громадянського суспільства, що складатиметься з громадян, які володіють високою свідомістю та здатністю проявити їі в повсякденній діяльності 3 забезпеченням сталого розвитку" [4].

В освітньому процесі національнопатріотичного виховання молодших школярів учитель керується історико-педагогічною спадщиною видатних українських педагогів минулого і сьогодення. Як зазначають М. Пантюк i Т. Пантюк, тут важливо засвоїти досвід розбудови національної, власне української школи. Адже саме у часи національного відродження посилюється увага до проблем мови та культури, на національному грунті будується система освіти, виробляється стратегія і тактика існування української школи з відповідним педагогічним виховним інструментарієм, формується плеяда педагогічних кадрів тощо [6]. Так, К. Ушинський у своїх працях говорив, що “питання патріотичного виховання мають базуватися на любові до Батьківщини, сім'і, народних традиціях, звичаях" [12]. Педагог вважав, що “немає людини без любові до Батьківщини, і ця любов дає вихованню вірний ключ від серця людини і могутню опору для боротьби з його поганими природними особливостями" [12].

Світоглядно-ціннісні настанови національнопатріотичного виховання починають формуватися ще у сім’ї, у стінах дитячого садка та школі. І. Огієнко, Г. Ващенко, С. Русова, наголошували на тому, що рідна мова, національні свята, традиції, обряди, християнське виховання, любов до свого народу, його творчості, надбань є основою змісту освітнього процесу.

Актуальними і сьогодні є слова С. Русової, яка стверджувала, що “національне виховання забезпечує кожній нації найширшу демократизацію освіти. Тоді його творчі сили не будуть покалічені, а навпаки, дадуть нові, оригінальні, самобутні скарби задля вселюдського поступу: воно через пошану до свого народу виховує в дітях пошану до інших народів" [9].

На думку В. Сухомлинського, виховання має триєдину мету взаємодія школи - родини громадськості. Він зазначав, що “у сім’ї шліфуються найтонші грані людини-громадянина, людини-трудівника, людини-культурної. Із сім’і починається суспільне виховання і саме тут, образно кажучи, закладається коріння, $з$ якого виростають потім і гілки, і квіти, і плоди. Сім'я це джерело, водами якого живиться повноводна річка держави" [10]. У педагогічній партнерській взаємодії сім'ї і школи розглядав проблеми виховання О. Вишневський. Педагог вважав, що національно-патріотичне виховання дитини розпочинається в сім’ї, з материнської мови, бабусиної казки і воно буде дієвим тоді, коли діти беруть участь у здійсненні звичаїв та обрядів, засвоюють народні пісні, є причетними до процесу народної творчості тощо [1].

Процес виховання формує національну свідомість особистості, розвиває уявлення про власну ідентичність, самобутність національної культури, визначає місце рідного народу серед інших етносів. Народ, у якого розвинена національна свідомість в спільноті та в кожного окремо, є самодостатнім і сильним, адже саме національне самоусвідомлення є рушійною силою особистості, соціалізує їі.

У процесі шкільного виховання патріотичних почуттів у молодших школярів учитель застосовує компетентнісний, міжпредметний підхід, при цьому використовує різні освітні технології, традиційні та інноваційні методи та форми. Формуючи почуття свідомого громадянина своєї держави, молодші школярі вчаться любити рідну мову, культуру, природу, історію Батьківщини. 


\section{НАЦІОНАЛЬНО-ПАТРІОТИЧНЕ ВИХОВАННЯ УЧНІВ ПОЧАТКОВОЇ ШКОЛИ}

Для досягнення системності у національнопатріотичному вихованні важливо визнати цінність і пріоритет рідномовного виховання. Досконале знання рідної мови також відбувається значною мірою в умовах сім’ї, оскільки рідна мова - це та, якою учні спілкуються вдома і вона може не збігатися $з$ державною. А також компонентами національно-патріотичного виховання $\epsilon$ відповідальне відношення до праці, відчуття радості та задоволення від отриманого результату, пошанування праці як джерела здоров'я і свободи тощо.

Важливою умовою ефективності національнопатріотичного виховання у молодших школярів $\epsilon$ їх залучення до позакласних та позашкільних заходів, які спрямовані на формування національно-патріотичних якостей, самоосвіту і всебічний розвиток особистості. Участь у проведенні масових заходів формують в учнів відчуття спільноти, чесноти любові, поваги, толерантності, гідності, чесності, довіри, відповідальності, справедливості.

Ефективними видами роботи є залучення учнів до волонтерської діяльності, вшанування полеглих воїнів і ветеранів, відзнаки державних i національних свят тощо. Основними формами та методами національно-патріотичного виховання, які застосовуються у школі є: практичні (патріотичні акції, проектна діяльність, флешмоби, акції пам'яті героїв Небесної сотні, волонтерство, доброчинна діяльність на підтримку воїнів операції об'єднаних сил); вербальні (бесіди, лекції, вікторини, конкурси, поетичні калейдоскопи, інформаційні досьє, бібліомарафони, “круглі столи”, “уроки мужності”); ігрові (ділові, сюжетно-рольові, пізнавально-розвивальні, інтелектуальні); інформаційно-комунікативні (інтернет-конференції, інтернет-конкурси, презентації учнівських проектів, онлайнопитування, обговорення на форумах); наочні (виставки, тематичні стенди, шкільні газети, перегляд кінофільмів патріотичної тематики, екскурсії в музеї, у майстерні художників, скульпторів, місцями народних промислів тощо); рефлексивні (самопізнання, самомобілізація, саморегуляція, самореалізація) [3].

Досягненню очікуваних результатів у національно-патріотичному вихованні молодших школярів сприяє вшанування традицій та звичаїв нашого народу, яких дотримуються в сім’ї і які підтримуються в школі. Молодші школярі люблять брати участь у народних життєвих дійствах - вертепах, колядуванні, гаївках, розмальовуванні писанок та інше. Діти ознайомлюються 3 народною творчістю, ремеслами, беруть участь у бесідах, зустрічах із захисниками нашої держави, екскурсіях, святах з використанням народних обрядів тощо. Під час навчання та у позашкільних заходах молодші школярі ознайомлюються з минулим, з видатними культурними та історичними діячами, виховують в собі повагу до ідеалів, за які проливається кров наших співвітчизників. Засобами усної народної творчості учителі розвивають в молодших школярів інтерес до української мови і культури в iii iсторичному розвитку. Таким чином національно-патріотичне виховання в умовах школи здійснюється на уроках усіх освітніх галузей на інтегративній основі щодо змісту, застосовуваних форм і методів, очікуваних результатів як життєво важливих компетенцій.

Школа є провідним суб'єктом національнопатріотичного виховання особистості і в персоніфікованій діяльності вчителя обирає шляхи свого становлення як національного, державного закладу, який прагне виховати патріота, громадянина української держави 3 активною життєвою та соціальною позицією, що любить свій народ і Батьківщину. В позаурочний час значну роль на особистісний розвиток дитини в цілому, а національно-патріотичне виховання зокрема відіграє родина, в якій формується характер особистості, їі внутрішній світ, відношення до навколишнього світу, життя, звичаїв, традицій, Батьківщини. Єдність сім'ї та школи забезпечує всебічний розвиток, гармонійність і цілісність особистості, а відтак збагачує інтелектуально-творчий потенціал народу, його духовність і культуру, виховує громадянина, здатного до самостійного мислення, суспільного вибору і діяльності, спрямованої на процвітання України.

Висновки. Національно-патріотичне виховання здійснюється упродовж усього свідомого освітнього процесу особистості в різноманітних умовах та ситуаціях в сім’ї, школі, позашкільних і молодіжних організаціях і об'єднаннях, забезпечує гармонійний розвиток, розвиває здібності, формує світогляд на основі надбань українського народу, збагачує духовність та особистісну культуру. Теорія і практика цього освітнього напрямку засвідчує зв” язок “національного” і “патріотичного” виховання як загального і конкретного, цілого і його складової. Узагальненим визначенням національного виховання $є$ трактування його як діяльність, що спрямована на формування в особистості патріотизму і шанобливого ставлення до України і національностей інших культур. Основною метою національного виховання $є$ передача молодому поколінню соціального досвіду, духовної 


\section{НАЦОНАЛЬНО-ПАТРІОТИЧНЕ ВИХОВАННЯ УЧНІВ ПОЧАТКОВОЇ ШКОЛИ}

культури народу, його ментальних настанов, світоглядних цінностей тощо. Національнопатріотичне виховання учнівської молоді це комплексна, системна і цілеспрямована діяльність різних соціальних інститутів щодо формування у молодого покоління патріотичної свідомості, любові до Батьківщини, турботи про її благо, готовності виконати свій обов'язок для захисту національних інтересів, цілісності і незалежності України. Учні початкової школи у процесі національно-патріотичного виховання формують ціннісне ставлення до українського народу, Батьківщини, держави, нації.

Школа у партнерській діяльності учителя, учнів, із залученням сім’ї та громадськості має невичерпні можливості для здійснення національно-патріотичного виховання молодших школярів. Перспективою подальших досліджень $\epsilon$ проблема національно-патріотичного виховання в школі в інноваційних формах діяльності учителя та учнів.

\section{ЛІТЕРАТУРА}

1. Вишневський O.I. Теоретичні основи сучасної української педагогіки. Посібник для студентів вищих навчальних закладів. Дрогобич: Коло, 2003. 528 с.

2. Докукіна О.М. Національне виховання дітей учнівської молоді. Енциклопедія освіти. Київ: Юрінком Інтер, 2008. C. 565-567.

3. Келембет Л. І., Фляк О. О., Риндич О. М. Патріотичне виховання дітей та учнівської молоді: теорія і практика. Національно-патріотичне виховання дітей та молоді у сучасному освітньому просторі України на засадах етнопедагогіки : матеріали Всеукр. наук.-прак. інтернет-конф. Івано-Франківськ : Місто НВ, 2016. C. $16-23$.

4. Концепція національно-патріотичного виховання URL: https://mon.gov.ua app uploads public

5.Національно-патріотичне виховання у закладах освіти: рекомендації URL: https://pon.org.ua/novyny/ 7258-naconalno-patrotichne-vihovannya-u-zakladahosvti-rekomendacyi.html

6. Пантюк М. П., Пантюк Т. І. Національний підхід та концепція вільного виховання у підготовці майбутнього вчителя до виховної роботи. Молодь $і$ ринок: шомісячний науково-педагогічний журнал. 2011. № 8 (79). C. $22-26$.

7. Пантюк М. П. Аксіологічні основи професіограми вчителя як суб'єкта виховання (історичний аспект) Педагогічний альманах: Збірник наукових праць Редкол. В.В. Кузьменко (голова) та ін. Херсон: КВНЗ "Херсонська академія неперервної світи", 2013. Вип. 20. C. $273-279.323 \mathrm{c}$

8. Пантюк М. П. Завдання національнопатріотичного виховання молоді у педагогічній спадщині вітчизняних педагогів кінця XIX-початку XX ст. Наукові записки Тернопільського начіонального педагогічного університету. Серія: Педагогіка. №1. Тернопіль. С. 23-27.
9. Русова С. Українська національна школа. Україна. 1991. №5. C.4.

10. Сухомлинський В. О. Батьківська педагогіка. Київ: Рад. шк., 1978. 263 с.

11. Ткаченко В.М. Патріотизм. Енцикллопедія освіти. / Акад. пед. наук України; головний ред. В.Г. Кремень Київ: Юрінком Інтер, 2008. 1040 с. С. 633-634.

12. Ушинский К. О нравственном элементе воспитания. Собрание сочинений: в 11 т. Т. 2. МоскваЛенинград: Изд. Аккад. пед. наук РСФСР, 1948. С. 425 489.

\section{REFERENCES}

1. Vyshnevskyi, O.I. (2003). Teoretychni osnovy suchasnoi ukrainskoi pedahohiky [Theoretical foundations of modern Ukrainian pedagogy]. Handbook for students of higher educational institutions. Drohobych, p. 528. [in Ukrainian].

2. Dokukina, O.M. (2008). Natsionalne vykhovannia ditei i uchnivskoi molodi [National education of children and students]. Encyclopedia of Education. Kyiv, pp.565567. [in Ukrainian]

3. Kelembet, L. I., Fliak, O. O. \& Ryndych, O. M. (2016). Patriotychne vykhovannia ditei ta uchnivskoi molodi: teoriia i praktyka [Patriotic education of children and students: theory and practice]. Natsionalno-patriotychne vykhovannia ditei ta molodi u suchasnomu osvitnomu prostori Ukrainy na zasadakh etnopedahohiky. materialy Vseukr. nauk.-prak. internet-konf - Nationalpatriotic education of children and youth in the modern educational space of Ukraine on the basis of ethnopedagogy: Proceedings All- Ukrainian ScientificPractical Internet Conference. (pp. 16-23.). IvanoFrankivsk. [in Ukrainian]

4. Kontseptsiia natsionalno-patriotychnoho vykhovanni (2015). [The conception of national and patriotic education]. Available at: https://mon.gov.ua app uploads public. [in Ukrainian].

5. Natsionalno-patriotychne vykhovannia u zakladakh osvity: rekomendatsii National and patriotic education in the educational institutions]. Available at: https:// pon.org.ua/novyny/7258-naconalno-patrotichnevihovannya-u-zakladah-osvti-rekomendacyi.html. [in Ukrainian].

6. Pantiuk, M. P. \& Pantiuk, T. I. (2011). Natsionalnyi pidkhid ta kontseptsiia vilnoho vykhovannia u pidhotovtsi maibutnoho vchytelia do vykhovnoi roboty [National approach and the concept of free education in the training of future teacher for educational work]. Youth \& market no. 8 (79). pp. 22 - 26. [in Ukrainian].

7. Pantiuk, M. P. (2013). Aksiolohichni osnovy profesiohramy vchytelia yak subiekta vykhovannia (istorychnyi aspekt) [Axiological bases of the professional profile of the teacher as a subject of education (historical aspect]. Pedagogical Almanac: a collection of scientific papers. (Ed.).V.V. Kuzmenko. Kherson, Vol. 20. pp. 273 $279.323 \mathrm{p}$. [in Ukrainian]

8. Pantiuk, M. P. Zavdannia natsionalnopatriotychnoho vykhovannia molodi u pedahohichnii spadshchyni vitchyznianykh pedahohiv kintsia XIX pochatku XX stolittia [The tasks of national and patriotic 
education of youth in the pedagogical heritage of native teachers of the end of XIX - the beginning of the XX century]. Scientific notes of Ternopil National Pedagogical University. Series: Pedagogy. Ternopil, no.1. pp. 23-27. [in Ukrainian].

9. Rusova, S. (1991). Ukrainska natsionalna shkola [Ukrainian National School]. Ukraine. No.5. p.4. [in Ukrainian].
10. Sukhomlynskyi, V. O. (1978). Batkivska pedahohika [Paternal education]. Kyiv, 263 p. [in Ukrainian].

11. Tkachenko, V.M. (2008). Patriotyzm [Patriotism]. Encyclopedia of Education. Kyiv, pp. 633-634. [in Ukrainian].

12. Ushinskiy, K. (1948). O nravstvennom elemente vospitaniya [About the moral element of education]. Collected works: in 11 volumes. Vol. 2. Moskva-Leningrad, pp. 425 - 489. [in Russian].

Стаття надійшла до редакції 27.09.2021

УДК 373.014 .5

DOI:

Інна Червінська, доктор педагогічних наук, професор кафедри педагогіки початкової освіти, Прикарпатського національного університету імені Василя Стефаника

Ореста Карпенко, доктор педагогічних наук, професор кафедри загальної педагогіки та дошкільної освіти Дрогобииького державного педагогічного університету імені Івана Франка

\section{БРЕНД ЗАКЛАДУ ЗАГАЛЬНОЇ СЕРЕДНЬОЇ ОСВІТИ ЯК ПОКАЗНИК ЙОГО КОНКУРЕНТОЗДАТНОСТІ В ОСВІТНЬОМУ ПРОСТОРІ РЕГІОНУ}

Акцентовано увагу на актуальності брендової проблематики, яка зумовлена глобалізаційними процесами розвитку світового співтовариства та інноваційним характером розвитку системи освіти. Сучасний заклад загальної середньої освіти виступає органічною компонентою иього багатогранного $і$ цілісного процесу, щзо зумовлено нормативними вимогами статуту та технологічністю освітньої діяльності. Процес формування бренду закладу освіти включає різноманітні ефективні прийоми та інноваційні технології, які входять до добре продуманої і чітко спланованої системи стратегічного розвитку закладу загальної середньої освіти, сприяють формуванню та підтримці його позитивного іміджу. Увиразнюється освітній контент поняття “брендинг” як розроблена й апробована в сучасному освітньому просторі технологія, яка характеризується як добре знаною й поширеною технологією створення успіху діяльності закладу освіти. Інноваційна школа як освітній бренд повинна бути конкурентоздатною на ринку освітніх послуг регіону, здійснювати певний вплив на свідомість споживачів / здобувачів освітніх послуг, щуо сприятиме поміркованому й усвідомленому вибору інноваційного “брендового” закладу освіти.

Ключові слова: заклад освіти; бренд; брендинг; інновачійні технологї̈; траєкторія успіху; інноваційна икола.

תim. 8.

Inna Chervinska, Doctor of Sciences(Pedagogy), Professor of the Pedagogy of Primary Education Department,

Vasyl Stefanyk Precarpathian National University

Oresta Karpenko, Doctor of Sciences (Pedagogy), Professor of the General Pedagogy and Preschool Education Department, Drohobych Ivan Franko State Pedagogical University

\section{BRAND OF OF GENERAL SECONDARY EDUCATIONAL INSTITUTION AS AN INDEX OF COMPETITIVENESS IN THE EDUCATIONAL SPACE OF THE REGION}

The authors emphasize the relevance of brand issues, which is due to the globalization processes of the world community and the innovative nature of the education system. It is pointed out that the modern institution of general secondary education is an organic component of this multifaceted and holistic process, which is due to the regulatory requirements of the statute and the manufacturability of educational activities.

The article, based on the results of content analysis of scientific literature and study of practical experience of innovative educational institutions, reveals the specifics of brand formation of general secondary education as a factor of its competitiveness in the modern regional educational space.

There is a demand for brand ideology, based on socio-cultural, socio-economic challenges of society, the spread of information-digital and cultural paradigms that determine the transformation of the education system, understanding the value of quality knowledge throughout life, the relevance of self-development and self-improvement Researchers point out that the process of brand formation of an educational institution includes a variety of 